\title{
BOARD COMPOSITION AND ORGANIZATIONAL PERFORMANCE: ENVIRONMENTAL CHARATERISTICS MATTER
}

\author{
*İrge Şener \\ **Abdülkadir Varoğlu \\ ***Selim Aren \\ *Çankaya University, Turkey \\ **Başkent University, Turkey \\ $* * *$ Gebze Institute of Technology, Turkey
}

\begin{abstract}
Concern for board of directors considerably increased with the recent developments in the corporate governance field. Despite that extensive research was conducted, the understanding of the board and its effects is still limited. This is mainly because that the majority of the corporate governance research focused mostly on the direct relation of board characteristics with organizational outcomes, and neglected the effect of intervening variables, leading to inconclusive research findings. Deriving on this limitation, in this study, the effect of board composition on organizational performance was investigated for different environmental conditions, which are measured in terms of munificence and dynamism of the industry in which the organizations operate and product complexity of the organizations. In addition, the moderating effects of these dimensions of organizational task environments on the relationship between board composition and organizational performance were also addressed. Building on resource dependence theory, it is suggested that under different environmental conditions, different compositions of boards will positively influence organizational performance. Based on the data from 80 companies which shares are publicly traded in Istanbul Stock Exchange, the findings indicate that the effect of board composition on organizational performance vary among different environmental conditions.
\end{abstract}

Keywords: Board Composition, Organizational Performance, Munificence, Dynamism, Complexity

\section{INTRODUCTION}

Globalization and liberalization of financial markets, corporate governance scandals and increasing demands of stakeholders for accountability and transparency of organizations, brought the roles and tasks of board of directors (BODs) to the center of corporate governance debate (Ingley and Van der Walt, 2005). Not only, high profile corporate scandals and failures of the recent history, but also the recent global financial crisis are mainly related to the activities of the boards. Since BODs are viewed to be a fundamental component of corporate governance; developments in the corporate governance field encouraged BODs concern for organizational strategy which was previously controlled by the General Manager of the organization (Ruigrok et al, 2006). This is therefore an indication of the vitality of boards (Pye and Petigrew, 2005) who are the final institutional decision makers (Nickolson and Kiel, 2004).BODs have various and important roles (Finkelstein and Money, 2003). According to Zahra and Pearce (1989), the main roles of BODs are control, service and strategy. Realization of these roles mainly depends on the characteristics of boards (Pearce and Zahra, 1992), which affect the financial performance of organizations. Daily, Johnson and Dalton (1999) identified more than 20 definitions of board structure, which researchers encountered in the literature. However, most researchers concentrated on the three most important characteristics of BODs, which are leadership structure, board size and board composition (Van den Berghe and Levrau, 2004). The view that board characteristics are important determinants of organizational performance is widely accepted (Zahra and Pearce, 1989; Pettigrew, 1992; Johnson, Daily and Ellstrand, 1996). Although, this is an enduring topic in the literature, no consensus exists whether there is a substantive relation between the characteristics of BODs and the performance of their organizations. Research reviews and meta-analyses 
consistently indicate equivocal relationships between board composition, leadership structure and organizational performance (Zahra and Pearce, 1989; Johnson et al, 1996; Dalton et al, 1998 and 1999).

This research stream considerably emphasized the direct impact of board characteristics on organizational performance, however neglected the intervening variables in this relation. The environmental context is a key contingency for the organizations, it both enhances and constraints organizational activities. Since different environments have different economical, technical and social features, the structures and strategies of the organizations operating in different environments differ from each other. Utilization of environmental features in the relation between board characteristics and organizational performance could shed valuable insight to the inconclusive findings of the previous research. In this study, focusing on these discussions, it was aimed to investigate the effect of board composition, measured in terms of insider director, outsider director and affiliated director presentation, on organizational performance in different industries. BODs are in general the main decision-making body of organizations in Turkey and they are primarily responsible for the fate of their organizations, therefore the study of the effect of these groups on organizational performance exists as an important research topic in Turkish context.

The first draft of this article was presented at 7th International Strategic Management Conference ( 30 June - 02 July, 2011).

\section{THEORETICAL FRAMEWORK}

Board of Directors (BODs) has an important role in the management of organizations. Since, BODs are considered to be one of the important governance mechanisms, these groups are increasingly being hold responsible for the organizational performance. For this reason, many studies from diverse fields, including law, economics, finance, sociology, organizational theory and strategic management, focus on BODs (Kiel and Nicholson, 2003). The performance of the organizations is dependent on the realization of the roles of BODs. These roles are both important and numerous (Finkelstein and Money, 2003). Johnson, Daily and Ellstrand (1996) suggest that the most emphasized roles of BODs in the literature are control, service and resource dependence roles. The control role entails directors monitoring managers as fiduciaries of stockholders, hiring and firing executives and determining executive compensation. The service role, on the other hand, involves advising executives on administrative and other managerial issues as well as actively initiating and formulating strategy. Finally, the resource dependence role views the board as facilitating the acquisition of resources critical to firm success. Hillman and Dalziel (2003) assert that, monitoring as well as resource providing are considered by BODs to be an integral part of their board activities.

Agency theory being the dominant framework (Zahra and Pearce, 1989; Daily, Dalton and Cannella, 2003), researchers employed various theoretical perspectives (i.e. stewardship theory, managerial hegemony theory, stakeholder theory, institutional theory, resource dependence theory) for the study of BODs. Within the frame of agency theory, it is assumed that BODs control the opportunistic behaviors of the managers; therefore, these groups represent the primary internal control system that fit the interests of shareholders and managers, (Jensen, 1993). According to Fama and Jensen (1983), BODs form "the apex of internal decision control system" of the organizations; since they are the main control mechanism for the organizations, and are authorized for the control of organizational decisions. Agency theory is appropriate for the control and supervision roles of BODs. However, different theoretical perspectives are required for the resource provision roles of BODs, which is among the most important roles of board members (Zahra and Pearce, 1989; Johnson et al, 1996; Daily et al, 2003). The theoretical framework for such roles is based on resource dependence theory (Pfeffer and Salancik, 1978). Consideration of these roles of BODs had resulted that a considerable amount of research to be undertaken within the frame of resource dependence theory. Resource dependence theory (Pfeffer and Salancik, 1978) presents an alternative to the agency theory. The theory considers BODs as a mechanism that reduces the environmental uncertainty (Pfeffer, 1972), manage the external organizational dependencies (Pfeffer and Salancik, 1978), behave as a coaptation mean in order to ensure the resources that the organizations are in need of (Zahra and Pearce, 1989) and, increase organizational legitimacy (Pfeffer and Salancik, 1978; Zahra and Pearce, 1989). The primary focus of resource dependence theory is the fact that the organizations should interact with its environment as much as it is necessary. Within the frame of resource dependence theory, organizational needs to access environmental resources, emerge as a vital issue for the survival. Organizations are considered as an open system that is dependent on other organizations for the provision of important resources (Pfeffer and Salancik, 1978). It is assumed that the success of the organizations is based on their abilities to provide and control the external resources (Aldrich and Pfeffer, 1976). The mechanisms that 
administer these external dependencies are BODs (Pfeffer and Salancik, 1978).Resource dependence theorists considers BODs as, important actors who act as boundary-spanners in order to ensure that the managers get the necessary knowledge on time; and the groups who are beneficial for the provision of the resources required for organizational activities (Zahra and Pearce, 1989). According to resource dependence theory, since each board member brings in different resources and network to the organization, BODs are selected according to their resource provision capabilities, which are important for the organization. Resource dependence role encourage the access to the critical assets, capabilities and knowledge that are critical and may otherwise unavailable to the organization (Pfeffer and Salancik, 1978). Dalton and Daily (1999) state that, resource dependence roles of BODs which forms a link to organizations' external environment, are the basis for organizational success. By ensuring the access to the resources that the organizations are dependent on, BODs contribute to the strategic organizational decisions (Hillman and Dalziel, 2003). BODs have an important role of assuring essential resources from the external organizational stakeholders by their personal relations (Pfeffer and Salancik, 1978; Zahra and Pearce, 1989; Pearce and Zahra, 1992; Johnson, Daily and Ellstrand, 1996). When BODs are appointed for their expertise, organizations can successfully cope with environmental uncertainty which will lead to better organizational performance. Thus, the board structure will be formed in accordance to resource dependencies of organizations (Hillman, Cannella and Paetzold, 2000).

Board structure refers to the formal organization of the board of directors; its major dimensions are size and the division of labor between the board chair and the CEO. The size of a board is straightforward, defined by the number of directors. CEO duality refers to the situation in which both titles are held by one person. In contrast to structure, the composition of a board of directors defines the affiliations of each director (Finkelstein and Hambrick, 1996: 212,213). In the literature, the board composition is usually defined based on insider and outsider directors. Insider board members are the directors who are currently serving as company officers, whereas outsider board members are the directors who are "non-management members of the board" (Johnson, Daily and Ellstrand, 1996). Outsider directors are not necessarily independent directors; some of them may have ties with the company or company management through family or business relations (Hillman et al, 2000; Peng, 2004); thus these directors are affiliated with the company. Affiliated directors can form interlocking relations between the companies. Interlocking directorates occur in case that a board member of the organization, at the same time acts as the board member of another organization (Pfeffer and Salancik, 1978; Boyd, 1990). In such a case, interlocking directorates are considered as a coaptation mean with the other organizations which are important for the organization (Pfeffer and Salancik, 1978). In the literature, the research findings about the impact of all of these defined directors who forms the boards, on organizational performance are equivocal (Dalton et al, 1998 and 1999). One of the reasons of this ambiguity is that most of the research on board composition did not emphasize the environmental context in which the organization and BODs are embedded in.

\section{Environmental Context}

Since the dominant theoretical framework of the research related with BODs is the agency theory, researchers for a long period focused on the control roles of the board members and therefore to the internal environment of the organization. Apart from the control roles of BODs, resource dependence roles of board members provide a link to the external environment (Dalton and Daily, 1999). Therefore, in the research on BODs with a resource dependence perspective, it is crucial to consider environmental dimensions in which the organizations operate in. The internal and external organizational conditions determine the composition of the characteristics of board members and as a consequence the organizational performance (Zahra and Pearce, 1989). Pfeffer (1972) indicate that board composition is related to the organization's need to deal with its environment. However, in most of the previous research about BODs, the effect of environmental factors was not considered (Boyd, 1990).

In the recent research (Brouthers et al, 2000; Goll and Rasheed, 2005), it is discussed that environmental conditions may have an effect on the relation between the characteristics of BODs and organizational performance. Research on the resource provision role of BODs indicate that one of the factors that influence board size and composition is the environmental uncertainty (Pfeffer and Slancik, 1978; Pearce and Zahra, 1992). In order to overcome environmental resource constraints, an appropriate board composition could be effective (Zahra and Pearce, 1989). Environment is somewhat defined as "everything else" outside the organization (Duncan, 1972) and it is conceptualized in terms of general and task environments (Dill, 1958), where task environment is all aspects of the organization's environment which are potentially relevant to organizational goal setting and goal attainment. The 
task environment focuses upon the forces affecting the industry. Dess and Beard (1984) identified three broad dimensions of organizational task environments, as munificence, dynamism and complexity. The authors indicate that these dimensions are important for decision making since they are directly related to uncertainty.

According to Dess and Beard (1984), munificence is the relative level of current resources and it represents the capability of the environment that foster organizational growth. In munificent environments, organizational concern is about different purposes but not their existence, since sustainability of organizational existence is relatively easier than in other types of environments (Castrogiovanni, 1991). Resource dependence theory suggests that, the need for external resources and information determine the degree of environmental dependence (Boyd, 1990). Organizations face different levels of dependencies. The environment is considered as a pool of resources and the degree of resource munificence is defined as environmental munificence (Dess and Beard, 1984; Castrogiovanni, 1991). Munificent environments provide surplus resources (Castrogiovanni, 1991). Such environments reduce the resource dependencies (Boyd, 1990) and the competition for the resources (Dess and Beard, 1984). As a consequence, in munificence environments, without mergers, organizations could easily acquire resources for enhancing brand awareness, creating demand and achieving future growth (Pfeffer and Salancik, 1978). From the resource dependence perspective, insider directors have the internal knowledge about the internal operations and business processes. According to Forbes and Milliken (1999), insider directors are well acquainted, familiar to work together on a regular basis and have a comprehensive understanding of the organization's business. Boards dominated by insiders provide a medium for decision-making (Judge and Zeithaml, 1992) and conflict resolution (Boeker and Goodstein, 1993). Baysinger and Hoskisson (1990) indicate that inside directors have the knowledge and information to appropriately assess strategic decisions.

Facing scarce environmental conditions, especially top managers' strategic decisions are based on fewer communication and direct control (Yasai-Ardekani, 1989). Therefore, in the environments that are not munificent, the effect of presentation of insider directors in the boards is more, when compared with munificent environments. In the environments were resources are scarce, the organizational performance will depend on coherent decision making. Since insider directors are familiar with the routine organizational operations, decisions of these directors will be much efficient. On the other hand, in munificent environments since the resources are abundant, organizations should be in search for alternatives. Within this frame, it is suggested that although insider director proportion is favorable under scarce environmental conditions, in munificent environments this will not lead to better organizational performance. In sum, following hypotheses are proposed:

$H_{1}$ : In munificent environments, the effect of insider director representation on organizational performance is negative.

$\mathrm{H}_{2}$ : With increasing munificence, the effect of insider director representation on organizational performance weakens.

Dess and Beard (1984) define dynamism as the change, that is difficult to predict and which increase the uncertainty for the organizational members. More generally, dynamism is defined as the instability in the environment, the rate of change and the unpredictability of the environmental factors (Keats and Hitt, 1988; Priem et al, 1995). According to resource dependence theory, environmental dynamism which is a key component of environmental uncertainty is positively related to the firm dependence on its stakeholders for critical resources (Pfeffer and Salancik, 1978). In dynamic environments, top managers face ambiguous conditions, low levels of well-developed alternatives and less evaluation criteria for the selection of these alternatives ( $\mathrm{Li}$ and Simerly, 1998). Therefore, these factors oblige top managers to investigate evaluation of environmental conditions in a limited way, analyze rapid solutions for decision-making and enhance various suddenly emerging reactions. Dess and Origer (1987) suggest that in the environments with high levels of dynamism and complexity, organizations are in need of more division of labor in top management teams, in order to follow the rapidly changing segments of the environment. One of the predictions of resource dependence theory is that the presence of more outsider directors will help to gain access to the required resources of the organization and the organizational performance will be better. Pfeffer and Salancik (1978) indicate that outsiders provide managerial and informational skills that are not otherwise available to the organization, they can provide linkages to the external environment due to their information and resources, and they may facilitate initiatives between organizations. Boyd (1990) and Hillman et al (2000) suggest that during conditions of environmental uncertainty, organizations are likely to appoint outsiders to the board, who have easy access to resources. Outside directors are always able to furnish valuable resources that are 
not readily available to the company (Hillman et al, 2000). Therefore, it is proposed that:

$\mathrm{H}_{3}$ : In dynamic environments, the effect of outsider director representation on organizational performance is positive.

$H_{4}$ : With increasing dynamism, the effect of outsider director representation on organizational performance becomes stronger.

According to Duncan (1972), environmental complexity represents the number of the key components in the environment. Dess and Beard (1984) define complexity as the diversity in the environment and the intensity of the resources. Since the organizations are interacting with too many different competitors in a complex environment, these environments are characterized by intense competition and mutual dependence (Pfeffer and Salancik, 1978). According to Dess and Beard (1984), the executives of the companies operating in complex environments are much exposed to uncertainty compared to the other companies operating in noncomplex environments.

Environmental complexity leads to various demands of different groups, and organizations respond these demands by diversification (Pfeffer and Salancik, 1978). One of the ways to cope with complexity is the inclusion of directors who have access to the resources. Under the conditions of complexity, organizations will prefer outsider directors who have links for the provision of the resources necessary for organizational activities. Resource dependence theory indicates that in order to buffer the effects of environmental uncertainty, interlocks between the companies exist for the coordination of the interorganizational exchange of necessary resources (Pfeffer and Salancik, 1978). The appointment of representatives of interdependent organizations in boards provides access to essential resources and secures those resources through linkages to the external environment (Pfeffer \& Salancik, 1978; Hillman, Cannella and Paetzold, 2000). Such directors can play an important role in disseminating information across organizations (Burt, 1980; Palmer, 1983), reducing costs of coordination and scanning (Bazerman and Schoorman, 1983), and allowing comparisons of the knowledge of the other organizations (Dahya, et al, 1996). In line with this, the following hypotheses are proposed:

$H_{5}$ : In complex environments, the effect of affiliated director representation on organizational performance is positive.

$H_{6}$ : With increasing complexity, the effect of affiliated director representation on organizational

\section{METHODOLOGY}

\section{Sample and Measurement}

The companies whose shares are publicly-traded in İstanbul Stock Exchange (İSE) form the initial sample of this study. As of December 2009, there are 315 companies listed on ISE. The shares of the majority of these companies (74\%) are traded in the national market, whereas the others' shares are traded in secondary national market, collective products market, new economy market and watch-list companies market.

In collective products market, the shares of the companies which are specialized in investment, such as securities investment, venture capital and real-estate investment, are traded. In addition, those companies which have debts to state agencies and banks, or have accumulated losses, those which did not inform the public about their financial statements or other information demanded by the Capital Markets Board, are listed on watch-list companies market. All of these companies are excluded from the sample.

The total number of the companies, whose shares are traded in the national market, secondary national market and new economy market, is 255 . Most of these companies have their activities in manufacturing industry (59,6\%). Among the remaining companies, 20,8 \% of them have activities in services, mainly, wholesale or retail trade, hotels and restaurants, information services, education-health-sports and other social services, transportation-communication and storage, electricity-gas and water, construction and public works, and mining operations. On the other hand, 19,6\% of the companies provide financial services, such as banks, insurance, leasing and factoring companies. These companies are not included in the sample, since the accounting principles of their operations is different from the other companies, which forms a limitation for comparison with other companies. Besides, holding companies are also classified as financial service companies. Since holding companies consists of a variety of companies that have operations in different industries, they are not appropriate for the purposes of this study. 
When the financial services companies are excluded from the sample, the final sample resulted to be 205 companies. Among these companies, the information about 80 of them is included in this study (coverage: $39 \%$ ). These companies represent a total of 10 industries, 8 of which are manufacturing and 2 of which are non-manufacturing. There are 67 companies that have their activities in manufacturing industries, and 13 companies operating in non-manufacturing industries (Table-1).

Table 1: Sample of the Study

\begin{tabular}{|c|c|c|}
\hline & Frequency & Percent \\
\hline Manufacturing & 67 & 84 \\
\hline Food and Beverages & 12 & 15 \\
\hline Textile Products & 8 & 10 \\
\hline Paper Products, Printing and Publication & 8 & 10 \\
\hline Petroleum Products & 5 & 6 \\
\hline Chemical Products & 6 & 8 \\
\hline Other Mineral Products & 9 & 11 \\
\hline Machinery and Equipments & 12 & 15 \\
\hline Transportation Vehicles & 7 & 9 \\
\hline Non-Manufacturing & 13 & 16 \\
\hline Transportation, Communication and Storage & 5 & 6 \\
\hline Information Services & 8 & 10 \\
\hline Total & 80 & 100 \\
\hline
\end{tabular}

There are a total of 534 board members of the 80 companies within the sample, who was in charge in year-2009. Data on individual basis was collected for each board member, from company annual reports, websites of the companies or other related websites. Summary descriptive statistics for board members within the sample are presented in Table-2. For the purposes of this research, insider directors are defined as the board members who are also executives of their companies, outsider directors are the independent board members who are unaffiliated with their companies and other companies which are affiliated with the company, and affiliated directors are the board members who are also the board members of other companies that have relations with the company. The proportions of insider, outsider and affiliated directors for each organization are calculated by using simple ratios (percentage of insider / outsider / affiliated directors within the board). The dependent variable of this study is the organizational performance. For the measurement of organizational performance, Return on Assets (ROA) (the ratio of net income to total assets) for each company is calculated for the year 2009. It is observed that, boards within the sample are dominated by directors that are executives of other companies which are affiliated with the company $(77,90 \%)$. Presence of outside directors in the boards still remain to be low; only approximately $6,4 \%$ of the sample are formed by outside directors. In the boards of 61 companies $(76,2 \%)$, no outsider director is present. With respect to board size, the average number of directors present in the boards is not high. Boards in the sample are formed by approximately 7 members on the average.

Table 2: Board Characteristics

\begin{tabular}{|l|l|c|c|c|c|}
\hline \multicolumn{2}{|c|}{ Board Composition } & Frequency & Percent & Minimum & Maximum \\
\hline & Affiliated Directors & 416 & 77,90 & 0 & 4 \\
\hline & Inside Directors & 84 & 15,73 & 0 & 7 \\
\hline & Outside Directors & 34 & 6,37 & 0 & 11 \\
\hline \multicolumn{2}{|l|}{ Board Size } & Mean & Std. Dev. & Minimum & Maximum \\
\hline
\end{tabular}


Therefore, the sample consists of organizations that have their operations in various industries. The munificence, dynamism and complexity characteristics of the industries are examined; since these characteristics define and conceptualize the basic features of the organizations' task environments (Bluedorn, 1993).

Environmental munificence is measured as the growth rate of the industry (Dess and Beard, 1984). For munificence, Dess and Beard (1984) used different measures; which are growth, in sales, pricecost margin, total employment, value added, or number of enterprises. Among these measures, growth in sales is the best measure that represents munificence, according to the results of Dess and Beard's factor analysis (Wiersema and Bantel, 1993). Growth in sales was measured as the coefficient of the regression slope $(\beta)$, divided by the mean $(Y)$. Industry sales data was measured using industry income statements for the time period of 1998-2009. Environmental dynamism was measured as the variance in the growth rates (Dess and Beard, 1984). For the measurement of environmental dynamism, Dess and Beard proposed instability of, total sales, price-cost margin, employment and value added or the ratio of sales to the producers of the intermediary goods. For the measurement of dynamism, the instability of total sales was calculated as the standard deviation of the regression slope coefficient $(\sigma)$ divided by the mean (Y), for twelfth year time period (1998-2009). Environmental complexity is measured as the concentration of the resources in the environment (Dess and Beard, 1984). For the measurement of environmental complexity, Dess and Beard (1984) suggested geographical concentration of total sales, value added, total employment and number of establishments and specialization ratio. However, it was not possible to access to safe data about these variables. According to Wiersema and Bantel (1993), environmental complexity can best be conceptualized by the diversity of the activities undertaken by the company. Therefore, the authors measured the complexity with product specialization ratio. In line with this, in this study, the complexity of each organization was measured in terms of their product specialization.

\section{RESEARCH FINDINGS}

Means, standard deviations and correlations of the measures are demonstrated in Table-3. Board size is correlated negatively with industry munificence and positively with environmental complexity. Correlations between industry munificence and two of the board composition variables (insider ratio and affiliated ratio) exist; which is positive between munificence and insider ratio and negative between munificence and affiliated ratio. Besides, correlations between ROA and the same board composition variables (insider ratio and affiliated ratio) also exist. The correlation between ROA and insider ratio is negative, whereas the correlation between ROA and affiliated ratio is positive.

In order to test the effects of each board composition variable on organizational performance, the data were analyzed with linear regression analysis. Table-4 reports the results of the regression analyses. According to the results, among the board composition variables both insider ratio and affiliated ratio have a significant effect on ROA. The effect of insider director proportion on ROA is found out to be negative, whereas the effect of affiliated director proportion on ROA is found out to be positive. On the other hand, no significant effect is discovered between outsider director proportion and ROA. In most of the research on board of directors, board size is considered as a control variable. When board size is considered as a control variable in the relation of insider ratio with ROA, it is observed that the effect of insider director proportion on ROA slightly increased $\left(\beta=-.267, \mathrm{p}=.019, \mathrm{R}^{2}=.081\right)$ and whereas the effect of affiliated director proportion on ROA slightly decreased $\left(\beta=.326, p=.004, R^{2}\right.$ $=.115$ ). 


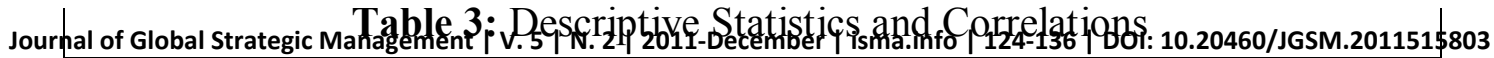

\begin{tabular}{|c|c|c|c|c|c|c|c|c|c|c|}
\hline & $\begin{array}{c}\text { Mean } \\
\mathbf{s}\end{array}$ & $\begin{array}{l}\text { Std. } \\
\text { Dev. }\end{array}$ & $\begin{array}{c}\text { Board } \\
\text { Size }\end{array}$ & $\begin{array}{l}\text { Out- } \\
\text { sider } \\
\text { Ratio } \\
\end{array}$ & $\begin{array}{c}\text { In- } \\
\text { sider } \\
\text { Ratio } \\
\end{array}$ & $\begin{array}{l}\text { Affili- } \\
\text { ated } \\
\text { Ratio }\end{array}$ & $\begin{array}{l}\text { Munifi- } \\
\text { cence }\end{array}$ & $\begin{array}{l}\text { Dyna- } \\
\text { mism }\end{array}$ & $\begin{array}{c}\text { Complex- } \\
\text { ity }\end{array}$ & $\begin{array}{c}\text { RO } \\
\text { A }\end{array}$ \\
\hline Board Size & 6,65 & 1,87 & 1 & & & & & & & \\
\hline Outsider Ratio & 0,07 & 0,14 & .031 & 1 & & & & & & \\
\hline Insider Ratio & 0,17 & 0,24 & -.200 & -.080 & 1 & & & & & \\
\hline $\begin{array}{l}\text { Affiliated } \\
\text { Ratio }\end{array}$ & 0,77 & 0,26 & .172 & $-.388 * *$ & $\begin{array}{c}- \\
.866^{*} \\
*\end{array}$ & 1 & & & & \\
\hline Munificence & 0,14 & 0,16 & $293^{-}$ & .048 & $.274 *$ & $-.300^{* *}$ & 1 & & & \\
\hline Dynamism & 0,18 & 0,08 & -.133 & .002 & .157 & -.154 & $.677 * *$ & 1 & & \\
\hline Complexity & 0,31 & 0,21 & $.279 *$ & .091 & -.119 & .059 & -.203 & -.194 & 1 & \\
\hline ROA & --- & 0,08 & .109 & -.132 & $-.278^{*}$ & $.335^{* *}$ & -.114 & .024 & -.015 & 1 \\
\hline
\end{tabular}

\begin{tabular}{|l|c|c|c|c|}
\hline \multicolumn{5}{|c|}{ Table 4: Regression Analysis - General Model (Main Effects) } \\
\hline \multicolumn{1}{|c|}{ Independent Variables } & $\begin{array}{c}\text { Standardized } \\
\text { Coefficients }\end{array}$ & $\mathbf{t}$ & Sig. & $\mathbf{R}^{\mathbf{2}}$ \\
\hline Insider Ratio & -.278 & $-2,561$ & $.012 *$ & .078 \\
\hline Outsider Ratio & -.132 & $-1,178$ & .242 & .017 \\
\hline Affiliated Ratio & .335 & 3,139 & $.002 * *$ & .112 \\
\hline * Significant at the 0.05 level * Significant at the 0.01 level & \\
\hline
\end{tabular}

The effects of each board composition variable on organizational performance were analyzed separately, for different levels of environmental dimensions. The means of each environmental variable determine their level. The values above the mean represent high level, where the values below the mean represent low level of environmental dimensions. As demonstrated in Table-5, the results indicate some significant relations. The negative effect of insider ratio on ROA is significant, when environmental complexity is low. Besides, the negative effect of outsider ratio on ROA is significant, when environmental dynamism is high. On the other hand, the significant effect of affiliated ratio on ROA is positive, when munificence is both low and high, when dynamism is high and when complexity is low. This effect is maximal, at high level of dynamism.

\begin{tabular}{|c|c|c|c|c|c|c|c|}
\hline \multirow[b]{2}{*}{$\begin{array}{l}\text { Independent } \\
\text { Variables }\end{array}$} & & \multicolumn{2}{|c|}{ MODEL 1} & \multicolumn{2}{|c|}{ MODEL 2} & \multicolumn{2}{|c|}{ MODEL 3} \\
\hline & & $\begin{array}{l}\text { Low Mu- } \\
\text { nificence }\end{array}$ & $\begin{array}{l}\text { High Mu- } \\
\text { nificence }\end{array}$ & $\begin{array}{c}\text { Low Dy- } \\
\text { namism }\end{array}$ & $\begin{array}{l}\text { High } \\
\text { Dyna- } \\
\text { mism }\end{array}$ & $\begin{array}{c}\text { Low } \\
\text { Complex- } \\
\text { ity }\end{array}$ & $\begin{array}{c}\text { High } \\
\text { Complex- } \\
\text { ity }\end{array}$ \\
\hline \multirow{4}{*}{ Insider Ratio } & $\mathrm{B}$ & -.227 & -.436 &,- 241 & -.383 & -.331 & -.246 \\
\hline & $\mathrm{T}$ & $-1,838$ & $-1,812$ & $-1,806$ & $-1,986$ & $-2,222$ & $-1,521$ \\
\hline & $\mathrm{P}$ & .071 & .091 & .077 & .059 & $.032 *$ & .137 \\
\hline & $\mathrm{R}^{2}$ & .052 & .190 & .058 & .146 & .110 & .060 \\
\hline \multirow{4}{*}{ Outsider Ratio } & $\mathrm{B}$ & -.082 & -.331 & .044 & -.514 & -.104 & -.146 \\
\hline & $\mathrm{T}$ & -.646 & $-1,314$ & .320 & $-2,873$ & -.663 & -.888 \\
\hline & $\mathrm{P}$ & .521 & .210 & .751 & $.009 * *$ & .511 & .381 \\
\hline & $\mathrm{R}^{2}$ & .007 & .110 & .002 & .264 & .011 & .021 \\
\hline \multirow{4}{*}{$\begin{array}{l}\text { Affiliated Ra- } \\
\text { tio }\end{array}$} & $\mathrm{B}$ & .269 & .526 & .205 & .604 & .369 & .319 \\
\hline & $\mathrm{T}$ & 2,195 & 2,312 & 1,524 & 3,632 & 2,513 & 2,021 \\
\hline & $\mathrm{P}$ & $.032 *$ & $.037 *$ & .134 & $.001 * *$ & $.016^{*}$ & .051 \\
\hline & $\mathrm{R}^{2}$ & .072 & .276 & .042 & .365 & .136 & .102 \\
\hline
\end{tabular}


Although the analyses reveal interesting findings, in munificent environments the effect of insider director representation on ROA is insignificant, when both of the munificence levels are considered. Therefore, the first hypothesis $\left(\mathrm{H}_{1}\right)$ is not supported. The effect of outsider ratio on ROA is found out to be insignificant in the general model. However, when environmental dynamism is high, this effect is negative. But, this finding also does not support the third hypothesis $\left(\mathrm{H}_{3}\right)$, since it was assumed that the effect would be positive in dynamic environments. Lastly, the fifth hypothesis $\left(\mathrm{H}_{5}\right)$ is not also supported, because according to the results, the effect of affiliated ratio on ROA is significant when complexity is low. It was hypothesized that this relation would be positive when complexity is high, however this effect is insignificant. Another regression analysis was conducted in order to test the moderating effects of environmental dimensions on the proposed relations. When the environmental dimensions were included in the analysis as moderating variables, it was found out that not only environmental munificence but also environmental dynamism and complexity have a significant effect on the relation between insider ratio and ROA. All of these effects are found out to be negative (Table-6).

\begin{tabular}{|l|c|c|c|c|}
\hline \multicolumn{6}{|c|}{ Table 6: Regression Analysis - Moderation Effects } \\
\hline \multicolumn{1}{|c|}{ Independent Variables } & $\begin{array}{c}\text { Standard- } \\
\text { ized } \\
\text { Cofficients }\end{array}$ & $\mathbf{t}$ & $\mathbf{S i g .}$ & $\mathbf{R}^{\mathbf{2}}$ \\
\hline Insider Ratio * Munificence & -.260 & $-2,378$ & $.020^{*}$ & .068 \\
\hline Insider Ratio * Dynamism & -.290 & $-2,675$ & $.009^{* *}$ & .084 \\
\hline Insider Ratio*Complexity & -.278 & $-2,556$ & $.013^{*}$ & .077 \\
\hline $\begin{array}{l}\text { Outsider Ratio * Munifi- } \\
\text { cence }\end{array}$ & -.165 & $-1,477$ & .144 & .027 \\
\hline Outsider Ratio * Dynamism & -.182 & $-1,637$ & .106 & .033 \\
\hline Outsider Ratio * Complexity & -.091 & -.808 & .422 & .008 \\
\hline $\begin{array}{l}\text { Affiliated Ratio * Munifi- } \\
\text { cence }\end{array}$ & .077 & .681 & .498 & .006 \\
\hline Affiliated Ratio* Dynamism & .342 & 3,210 & $.002 * *$ & .117 \\
\hline $\begin{array}{l}\text { Affiliated Ratio * Complex- } \\
\text { ity }\end{array}$ & .125 & 1,109 & .271 & .016 \\
\hline * Significant at the 0.05 level. & $* *$ Significant at the 0.01 level. \\
\hline
\end{tabular}

The effect of insider ratio on ROA under the conditions of environmental munificence is higher than the effect founded in the first model (Table-4). Although, this result indicates the moderating effect of environmental munificence on the relation between insider ratio and ROA, second hypothesis $\left(\mathrm{H}_{2}\right)$ is not supported. In addition, the results indicate no significant relation between outsider ratio and ROA, when each of the environmental dimensions is considered. Therefore, fourth hypothesis $\left(\mathrm{H}_{4}\right)$ is not also supported. Finally, the effect of affiliated director proportion on ROA is positive only when environmental dynamism is taken into consideration. The effect of affiliated director proportion on ROA is not significant under the conditions of complexity. This also indicates that, no support is found for sixth hypothesis $\left(\mathrm{H}_{6}\right)$.

\section{CONCLUSION AND DISCUSSION}

This study focused on the effect of board composition on organizational performance. This relation previously attracted the attention of many researchers; however the research findings were inconsistent. In this study, board composition was operationalized in three different ways and the effect of the three dimensions of the industries in which the organizations operate, was also investigated. Although the findings did not provide any support for all of the proposed hypotheses, some important concluding remarks are driven. First of all, the findings indicate that different measures of board composition lead to different results. In the governance literature, board composition is operationalized as not fewer than 20 ways, as the proportions of inside, outside, independent/interdependent and affiliated directors (Daily et al, 1999). There exists no optimal board composition for all organizations. Since each board member has different skills and knowledge, different types of board composition are required by different organizations. In this research, it is suggested that since organizations operating in same environment require similar resources, different board compositions will lead to better performance under different environmental conditions. 
The environmental characteristics which are measured in terms of munificence, dynamism and complexity have significant effects on some of the relations.

Affiliated director representation in the boards positively effect organizational performance, in the environments with different levels of munificence, when dynamism is high and when complexity is low. In munificent environments, in order to outperform their rivals, organizations should seek for different alternatives. In such cases, affiliated directors could bring in varieties of knowledge and resources from their own organizations; as a consequence, this will lead the organizations to evaluate different alternatives more easily and select the one that best fit organizational objectives more quickly. This is also valid in the environments where complexity is low. In the environments where there is high level of dynamism; the performance of the organizations, which are more rapid than others for the acquisition of the necessary resources, would be higher. It would be much quicker for affiliated directors to provide such resources to the organization, therefore the presence of affiliated directors in these environments would lead better performance. In this type of environments, outsider directors might not be effective for rapid provision of the resources. It would be much easier to access resources from another organization which is affiliated. On the other hand, the findings indicate that insider director proportion in each environment is not preferable, the presence of insiders effect organizational performance negatively. This might be related to the fact that in general insider directors are involved in daily organizational activities, so that it is difficult for them to follow all of the developments occurring in organizational environment. This therefore results that organizational performance to be lower than others.

These findings indicate that integration of environmental dimensions into the relation between board composition and organizational performance leads to a better understanding of the relation. As the findings demonstrate, the proportion of variation explained by the model (coefficient of determination $-\mathrm{R}^{2}$ ) increased with the inclusion of the environmental dimensions into the analysis.

There are some limitations encountered in this study. First of all, the sample size should be enlarged in order to understand the relations better. Besides, only organizations operating in 10 different industries are included in the sample, other organizations operating in different industries should also be included in the future studies. Organizational performance is measured in terms of ROA, it would be better to employ other performance measures that are directly related with environment such as resource acquisition and volume of resources. Most of the organizations in Turkey are family business; therefore, it would also be appropriate to include the number of family directors in the analysis. Apart from these limitations, the findings of this study revealed noteworthy insights for the effect of environmental dimensions on the relation between board composition and organizational performance. 


\section{REFERENCES}

Aldrich, H.E. and Pfeffer, J. (1976), Environments of Organizations, Annual Review of Sociology, 2, pp.79-105.

Bluedorn, A.C. (1993), Pilgrim's Progress: Trends and Convergence in Research on Organizational Size and Environments, Journal of Management, 19(2), pp.163-191.

Baysinger, B. and Hoskisson, R. (1990), The Composition of Boards of Directors and Strategic Control: Effects on Corporate Strategy, Academy of Management Review, 15(1), pp.72-87.

Bazerman, M. and Schoorman, F. (1983), A Limited Rationality Model of Interlocking Directorates, Academy of Management Review, 8, pp. 206-217.

Boeker, W. and Goodstein, J. (1993), Performance and Successor Choice: The Moderating Effects of Governance and Ownership, Academy of Management Journal, 36, pp.172-186.

Boyd, B. (1990), Corporate Linkages and Organizational Environment: A Test of the Resource Dependence Model, Strategic Management Journal, 11, pp.419-430.

Brouthers, K.D., Brouthers, L.E. and Werner, S. (2000), Influences on Strategic Decision- Making in the Dutch Financial Services Industry, Journal of Management, 26(5), pp.863-883.

Burt, R. (1980), Cooptive Corporate Actor Networks: A Reconsideration of Interlocking Directorates involving American Manufacturing, Administrative Science Quarterly, 25, pp.557-581.

Castrogiovanni, G.J. (1991), Environmental Munificence: A Theoretical Assessment, Academy of Management Review, 16(3), pp.542-565.

Dahya, J., Lonie, A.A. and Power, D.M. (1996), The Case For Separating the Roles of Chairman and CEO: An Analysis of Stock Market and Accounting Data, Corporate Governance-An International Review, 4, pp. 71-77.

Daily, C.M., Dalton, D.R. and Cannella, A.A. (2003), Introduction to Special Topic Forum Corporate Governance: Decades of Dialogue and Data, Academy of Management Review, 28(3), pp. 371-382.

Daily C.M., Johnson J.L. and Dalton D.R. (1999), On the Measurement of Board Composition: Poor Consistency and a Serious Mismatch of Theory and Operationalization, Decision Sciences, 30(1), pp.83-106.

Dalton, D. R., Daily, C. M., Johnson, J. L. and Ellstrand, A. E. (1999), Number of Directors and Financial Performance: A Meta-Analysis, Academy of Management Journal, 42(6), pp. 674-686.

Dalton, D.R. and Daily, C.M. (1999), What's Wrong with Having Friends on the Board? Across the Board, 36(3), pp.28-32.

Dalton, DR, Daily, CM., Ellstrand, AE. and Johnson, JL. (1998), Meta-Analytic Reviews of Board Composition, Leadership Structure and Financial Performance, Strategic Management Journal, 19(3), pp.269-290.

Duncan, R.B. (1972), Characteristics of Organizational Environments and Perceived Environmental Uncertainty, Administrative Science Quarterly, 17, pp.313-327.

Dess, G.G. and Beard, D.W. (1984), Dimensions of Organizational Task Environments, Administrative Science Quarterly, 29, pp.52-73.

Dess, G.G. and Origer, N.K. (1987), Environment, Structure and Consensus in Strategy Formulation: A Conceptual Integration, Academy of Management Review, 12, pp.313-330.

Dill, W.R. (1958), Environment as an Influence on Managerial Autonomy, Administrative Science Quarterly, 2, pp.409-443.Fama, E.F. and Jensen, M. C. (1983), Separation of Ownership and Control, Journal of Law and Economics, 26, pp. 301-325.

Finkelstein, S. and Hambrick, D.C. (1996), Strategic Leadership: Top Executives and Their Effects on Organizations. West Publishing Company.

Finkelstein, S. and Mooney, A.C. (2003), Not the Usual Suspects: How to Use Board Process to Make Boards Better, Academy of Management Executive, 17(2), pp.101-113. 
Forbes, D.P. and Milliken, F.J. (1999), Cognition and Corporate Governance: Understanding Boards of Directors as Strategic Decision-Making Groups, Academy of Management Review, 24(3), pp.489505.

Goll, I. and Rasheed, A. (2005), The Relationship between Top Management Demographic Characteristics, Rational Decision Making, Environmental Munificence and Firm Performance, Organization Studies, 26(7), pp. 999-1023.

Hillman, A. J., Cannella, A. A., and Paetzold, R. L. (2000), The Resource Dependence Role of Corporate Directors: Strategic Adaptation of Board Composition in Response to Environmental Change, Journal of Management Studies, 37, pp.235-254.

Hillman A. J. and Dalziel T. (2003), Board of Directors and Firm Performance: Integrating Agency and Resource Dependence Perspectives, Academy of Management Review, 28(3), pp.383-396.

Ingley, C. and Van der Walt, N. (2005), Do Board Processes Influence Director and Board Performance? Statutory and Performance Implications, Corporate Governance: An International Review, 13 (5), pp. 632-653.

Jensen, M.C. (1993), The Modern Industrial Revolution, Exit and the Failure of Internal Control Systems, The Journal of Finance, 48(3), pp.831-880.

Johnson, J.L., Daily, C.M., and Ellstrand, A.E. (1996), Boards of Directors: A Review and Research Agenda, Journal of Management, 22(3), pp.409-438.

Judge W.Q. and Zeithaml, C. P. (1992), Institutional and Strategic Choice Perspectives on Board Involvement in the Strategic Decision Process, Academy of Management Journal, 35, pp.766-794.

Keats, B.W. and Hitt, M.A. (1988), A Causal Model of Linkages among Environment Dimensions, Macro-organizational Characteristics, and Performance, Academy of Management Journal, 31, pp.570 -598 .

Kiel, G., and Nicholson. G. (2003), Board Composition and Corporate Performance: How the Australian Experience Informs Contrasting Theories of Corporate Governance, Corporate Governance: An International Review, 11(3), pp.189-205.

Li, M. and Simerly, R.L. (1998), The Moderating Effect of Environmental Dynamism on the Ownership and Performance Relationship, Strategic Management Journal, 19(2), pp.169-179.

Nicholson, G. J. and Kiel, G.C. (2004), Breakthrough Board Performance: How to Harness Your Board's Intellectual Capital, Corporate Governance, 4(1), pp.5-23.

Palmer, D. (1983), Broken Ties: Interlocking Directorates and Inter-corporate Coordination, Administrative Science Quarterly, 28, pp. 40-55.

Pearce, J. and Zahra, S. (1992), Board Composition from a Strategic Contingency Perspective, Journal of Management Studies, 29, pp.411-438.

Peng, M.W. (2004), Outside Directors and Firm Performance during Institutional Transitions, Strategic Management Journal, 25, pp.453-471.

Pettigrew, A.M. (1992), On Studying Managerial Elites, Strategic Management Journal, 13, pp.163182.

Pfeffer, J. (1972), Size and Composition of Corporate Boards of Directors, Administrative Science Quarterly, 21, pp. 218-228.

Pfeffer, J. and Salancik, G.R., 1978. The External Control of Organizations: A Resource Dependence Perspective. New York: Harper \& Row.

Priem, R. L., Rasheed, A. M. A. and Kotulic, A. G. (1995), Rationality in Strategic Decision Processes, Environmental Dynamism and Firm Performance, Journal of Management, 21, pp.913-929.

Pye, A. and Pettigrew, A. (2005), Studying Board Context, Process and Dynamics: Some Challenges for the Future, British Journal of Management, 16, pp. 27-38.

Ruigrok, W., Peck, S.I. and Keller, H. (2006), Board Characteristics and Involvement in Strategic Decision Making: Evidence from Swiss Companies, Journal of Management Studies, 43, pp.12011226. 
Van den Berghe, L.A.A. and Levrau, A. (2004), Evaluating Boards of Directors: What Constitutes a Good Corporate Board?, Corporate Governance, 12(4), pp.461-478.

Wiersema, M. F. and Bantel, K. A. (1993), Top Management Team Turnover as an Adaptation Mechanism, Strategic Management Journal, 14, pp.485-504.

Yasai-Ardekani, M. (1989), Effect of Environmental Scarcity and Munificence on the Relationship of Context to Organizational Structure, Academy Management Journal, 32, pp. 131-156.

Zahra, S.A. and Pearce, J.A. (1989), Boards of Directors and Corporate Financial Performance: A Review and Integrative Model, Journal of Management, 15, pp.291-334. 